\title{
Studies on College English Writing Teaching Based on Blog
}

\author{
Zefen Zhang \\ Foreign Language Department \\ Henan Institute of Science and Technology \\ Xinxiang Henan, China \\ Email address: eshui2010@163.com
}

\begin{abstract}
Different from traditional Internet communication manner, the Blog has its own advantages and features. It can increase communication between teachers and students, expand the field of study, the blog used in the teaching of English writing helps improve students' English writing ability, students should be encouraged to use the blog wisely to improve their English writing.
\end{abstract}

Key words-blog; advantages and weaknesses; application; English writing teaching

\section{Introduction}

Blog is short for Weblog. It is a website where regular entries are made (such as in a journal or diary) and presented in reverse chronological order. Blogs often offer commentary or news on a particular subject, such as food, politics, or local news; some function as more personal online diaries. A typical blog combines text, images, and links to other blogs, web pages, and other media related to its topic. Most blogs are primarily textual although many focus on photographs, videos or audio.

Blog was firstly put forward by Jorn Barger in Dec.1997. The next year, there were only a few blog websites online. But with the help of a software called "Pitas ", which is used to make blog websites, more and more blog websites came into being. As a result, more and more bloggers were born.

There are six categories of blog: 1 . The basic blog, blog in the simplest form. A single author for a specific topic to provide relevant resources, made a brief comment. These topics may relate to almost all areas of humanity. 2.Micro-Bo; That micro-blog, is now the world's most popular blog form, blog writers do not need to write complex articles, but only need to compose a mood within the 140 character text can be (such as Twitter, Xpress micro-Bo). Twitter logoTwitter (English, said: Push special) is outside a social network and micro-blog service site, which uses wireless networks, wired networks, communications technology, instant communication, is a typical application of micro-blog. It allows users to its own latest developments and ideas in the form of short messages sent to cell phones and personalized Web site group, rather than sent to individuals. 3. Family blog between relatives and friends. This type of blog consists of mainly constituted by relatives or friends, they are a kind of living area, a family or a group of project team members.
4.Collaborative style of a blog; With the group blog similar to its main purpose is made by the participants to discuss the issue in some way. Public published in a few years ago has been popular for a time, but because there is no lasting and effective business model and disappeared. Low-cost blog publishing system with this kind of public have the same goal, but the use of more convenient and cost spent on smaller, so it is more likely to survive. 5. Commercial, corporate, advertising-based blog. For the management of this type of blog sites similar to those normally WEB ad management. Business blog is divided into: CEO blog, corporate blog, "leaders" blog and so on. Public relations and marketing communications as the core of the blog application have been proven to be the mainstream of commercial blog applications.

There are other blogs such as Warblog(produced by Matt Welch ); Journal blog and Diary blog; Knowledge Log、 Klog、 K-Blog; News blogs; Pundit blog; Tech blog; Groupblog; Moblog; Videoblog; Audioblog; Fotolog; Digest blog.

The word "blog" comes from English blog which is the abbreviation of " web log” that means diaries of navigation, while the Chinese "blog" begins to spread from the moment when "blog of Chinese” was named after Fang Xiao-dong and Wang Jun-xiu in the internet on August $8^{\text {th }}$. The contents and purposes of blog differ greatly. They rang from news about companies, individuals to diaries, photos, poems, poses even the publication of scientific fictions. Bloggers are those that write web logs or blogs. The blog has lots of resemblances with personal home page in form, but it has its own specific features which render it become convenient, personal, instantaneous: organizing contents in the sequence of time; constructing study group through connection; offering room and convenience for accumulation of knowledge and for communication; serving as a tool to manage knowledge through classifying and searching.

The rapid development of science and technology make the education mode must also keep pace with the time, the blog used in the teaching of English writing breaks the traditional English teaching model. Using blog as a new kind of teaching methods help students master a modern kind of English writing tool and stimulate students' writing interest. The interest is a kind of tendency to explore certain thing or certain activity. It is the most realistic and evolutional factor in 
study motivation and it is the primary resource of study dynamic. Teachers offer favorable help, and allow students to write compositions and hand in their compositions in their own blogs, which greatly enhance students' writing interest. Students making use of computer to write compositions can make students more suitable to modern life, meanwhile, the functions of computer like typesetting, revision, spelling and grammar examination let students further improve their own tasks and save teachers' lots of time in correcting unimportant mistakes in students' compositions to a large extent.

\section{Previous Studies}

At the beginning of this century especially in the latter half of 2002, the blog got rapid development, because of its advantages which are easy to search, share, communicate and that are not confined by time. The study pattern based on blog provides English learners with more widen virtual and free environment which can make students enjoy various study resources. As a new kind of accumulating knowledge, managing knowledge and ex-changing, the blog is concerned by educators home and abroad, thus producing the new conception of "Education Blog”.

In foreign countries, many linguists and language-educating experts have made enormous verifiable studies regarding the blog as method of teaching and communicating. The American professor Trent Baston uses the pattern of internet Portfolio to carry out writing teaching and gain great success. Huffaker finds that the blog can dynamic students' writing process, enhance their writing interest and ability. At home "blog" teaching also gradually gains scholars' and educators' emphasis. Zhengjing YU deems that with the help of the blog, English teachers authentically become guiders of study resources and students become real constructors in exercising and learning's active work, meanwhile, it can revive students' active study, which makes them become active cooperators in the process of teaching and learning. Wenjuan Wang, Liu Wei believe that mutual talks are like peer assessment and peer interaction form a "mirror refraction” which is conductive to make objective analysis and evaluation about students' own works, thus they can develop rational plans and new targets for further trainings. Xuefeng Zhang analyses the applying of "Education blog" in higher education; Xiaoying Guo contends constructing the model of college English Writing.

Through analyzing the present studies condition that the blog is applied to teaching at home and abroad, the majority of researchers focus on advantages brought by applying the blog to writing teaching. This paper will further analyze its advantages based on the use of blog and its potential shortcomings.

\section{Concrete Patterns}

\section{A Theoretical Basis}

Communicative Theory. The essence of English teaching is communication between teachers and students, between students and students, teachers and teachers. "Communicative competence" is proposed by hymns based on Chomsky's "Linguistic competence", which emphasizes language teaching should shift the importance from constructive teaching to communicative competence. Taylor emphasizes meaningful communication which encourages students to join in solving problems and finishing tasks. Communicative theory contends that teachers impart linguistic knowledge in activities in which language is applied and teachers should elaborately organize and design various linguistic practical activities. The peer work among students, in fact, is one of the applying of communication teaching methods in the process of practical teaching, which is intended to make students finish certain tasks naturally and efficiently through communication in learning language.

Constructivist Theory. Constructivist theory is one of the branches of cognitive theory earliest proposed by Swiss famous psychologist Piaget in the 1960s. The main content of constructivist in study pattern is that: acquisition of knowledge isn't imparted by teachers but acquired through the manner of meaning's construction under social and cultural situation and with the help of others including teachers using necessary study materials. This theory emphasizes that students are the center in the process of studying. The teacher's core should shift from the teacher to students. Therefore, teachers use resources including internet to help students construct basic knowledge of writing.

The Closet District of Development. The theory is proposed by Russian psychologist and philologist Vogotsgy in the 1930s based on the theory of cultural and historical development. Vogotsgy distinguishes two kinds of levels of individual's development: realistic development level and potential development level. The realistic development level is that individual can reach the level by the individual's independent activities. While the potential development level is that the individual can reach with the help of adults or more mature than the individual. The area between the two levels is the closet development district. When two or more cooperators resolve problems, they take active part and work together.

\section{B Three Patterns}

According to different purposes, the blog applied in English writing teaching can be classified into three patterns: individual study pattern, teachers' teaching pattern and class study pattern.

The individual study pattern is based on students' personal blog and is intended to let students study independently through patterns of searching problems, showing achievement, accumulating resources and constructing community, ultimately to improve students' writing ability. The technology of blog is simple and available, thus students can create an authentic communication situation under the virtual internet environment without knowing profound knowledge about internet, and students can build and manage their own blog website without website's designation. Students can write their tasks in classes, study methods and experience or personal impression and contemplation on the individual blog. In addition, students can actively and independently search relevant study resources and materials then classify them into their own blogs. Students can add addresses of blogs they like into their own blogs, and then through connection get timely 
others' latest knowledge. Students also can reflect themselves and revise their writings through teachers' and classmates' evaluation.

Teacher's teaching pattern is dominated by teachers' blogs. Teachers use blogs to organize and manage writing teaching. Teachers assign writing tasks on their own blogs making students get clear guidance. Furthermore, teachers should try any chance to put study plans and requirements on an obvious place in their blogs so as to offer instruction. Teacher can offer teaching plan, reading texts, relevant internet connection or other blog community's connection. Students can find document resources or clue of document relative to study tasks. Then teachers can timely solve problems and confusions students meet. Teachers also can visit students' blogs respectively and solve individual problems, which is more effective. Thus it can further facilitate students' writing study. Finally, through blog teachers can express their own reflections and students can know more about teachers. Thus, it not only breaks communicative barriers between teachers and students, boost communication and build good relationship between them but also help students know teachers' thought patterns and emotive features. All these are good for students' study and growth.

Class study pattern is based on "class blog" which is a collective blog. All members of the class have rights to add contents to the blog. Such a study model is helpful to build study resources, study communication and launch teamwork study. Among members they can exchange opinions, express suggestions and evaluations.

\section{Analysis of College English Writing Teaching Based on Blog}

\section{A The Advantages}

Firstly, the blog writing teaching focuses on students making their personality outstanding. In the blog writing teaching, students begin with basic sentences from accepting writing arrangement, beginning to write, handing in composition to mutual evaluation. Students become the hosts of writing activities and teachers play a role as guiders, find out problems timely in students' writings finally improving writing ability.

Secondly, the blog helps teachers search and offer rich study resources before classes. Teachers send study resources' relevant connection to their blogs. Students get to know instantly about writing contents and make good preparation for it. Meanwhile, the feature of class-platform of blog expands writing time and space greatly. Thus practicing writing isn't confined in classes instead, it can operate anytime and anywhere. Teachers and students can also communicate and comment on writings willfully.

Thirdly, the blog offers authentic communicative environment, improves feedback productivity and boosts active study. In traditional English classes, some intravenous students aren't adept at expressing their own opinions and feelings but the blog creates a real communicative platform providing teachers and students with more chances to communicate. Simultaneously instantaneous communication enhances productivity of feedback which brings lots of helpfulness to teacher's teaching and student's learning. In the process of communication and feedback, students' self-teaching ability is also improved. The blog shifts the purpose of writing a composition without grammatical errors to communicating with others in English realizing the real purpose of writing.

Finally, when the blog is applied to English writing teaching, it can change students' attitudes toward writing. Students spend little time in correcting mistakes in their writing. Students can spontaneously revise their spelling and grammatical errors, when such a behavior is repeated frequently student' stupid mistakes will decrease gradually and their writing ability gets some progress, meanwhile, it can lessen teachers' task of revising.

\section{B The Disadvantages}

The coin has two sides. Thus, the disadvantages of college English writing teaching based on blog also exist. The application of blog in the foreign language teaching incurs a new challenge to the English teachers' position. Some people argue that it will eventually replace the status of teachers in the teaching process. Learners can make use of their own computer to complete the detailed annotation in their textbook, to introduce some culture background knowledge of the relevant document, and to supply reading material and some keys to the exercises and some self-testable tasks. In a sense, this seems to reduce the workload of the teachers and weaken the importance of the teachers' role. While in fact, this high-tech application put forward the higher requirements for the comprehensive quality of the teachers. The teachers must be clear about their own orientation in blog-based writing teaching and must well know the abilities they must master in the contemporary age.

Firstly, because most of students have got used to traditional writing teaching plus that some students from poor areas may be low efficient in using the internet. Therefore, to these who just began to use this new kind of writing model, teachers should give those techniques direction and guidance in learning methods and psychological transition in writing.

Secondly, under such a writing model the exercises become so frequent that teachers can not carefully correct all students' writings thus there should be an effective system of tracking and feedback between teachers and students. For example, the charge man gives an average grade based on mutual comment of the whole group and records, thus teachers can give specific guidance to poor students accordingly.

Thirdly, because of rich internet resources, it's most likely for some lazy students to copy others' blogs. As for this problem, teachers can declare all websites including English blogs to the whole class. Thus, all students can supervise each other. Furthermore, teachers can try each chance to limit style contents to a certain range through class discussion or create situation in order to avoid the possibility of copy.

Then, under this new writing model students' attention is more diverted to writing contents, which leads that language's usage and simplicity are neglected. Therefore, during original 
period of writing, teachers have to attach much importance to usage of students' basic language, such as expanding or narrowing exquisite texts of students.

Finally, it's inevitable that students spend more time on the internet. Then some students take advantage of this chance to play computer games, they waste plenty of time unconsciously. Meanwhile, too much time spent on the internet will be harmful to health. As we all know, the computer always produces lots of detrimental radiant to our bodies, which undermines our health.

Certainly, many other problems may rise continually. It needs teachers to analyze timely, solve and summarize experiences thus this new writing teaching model can gradually be polished and developed in practical process.

\section{V . The Abilities of Contemporary Teachers}

In the process of teaching, teachers should let the classroom teaching diversified, visual and vivid, mobilize the students' initiative and enthusiasm, to cultivate the students' innovation ability and optimize the classroom teaching and improve the teaching efficiency. At the same time, the requirements for the abilities of the contemporary college English teachers become higher and higher.

\section{A The Ability of Lifelong Learning}

The implementation of the blog-based teaching means the teachers can not only be the enforcer, but also the developer of the special course. The teachers must enter the classroom teaching as a researcher to discover problems and collect data, and use the teaching practice experience to make analysis from different levels and different visual angles and at last make their own practice and the teaching content from the theoretical understanding and construction.

\section{$B \quad$ The Ability of Acquiring Information and Knowledge}

In order to make the efficient courseware for the students, the English teachers must acknowledge the different language culture forms which are used in different disciplines, on different occasions, for different purposes. And then adopt different kinds of guide and help the students to learn the judgment and choice and tradeoff, at last, make the students have the ability to find and solve problems.

\section{The Ability of Mastering Language Psychology}

The students' foreign language ability is not born, in order to observe and judge the students, the teachers have to use the language psychology and cultivate the students' correct and authentic language thinking ability by their efficient learning and practicing. Besides, the teachers should be familiar with the individual difference in students' psychology, such as intelligence and individual character and so on, so that the teachers can give their students enlightenments in the students' interest and enthusiasm and inspiration in the students' learning motivation. Moreover, teachers must understand the students' specific level, and then make the effective learning plan for their students.

\section{Conclusion}

In conclusion, the blog provides teachers and students with a good chance to study on the internet, which not only changes teachers' teaching manner but also change students' study methods and their ways of thinking. English writing teaching based on blog has presented obvious advantages. Technology of blog brings chances and challenges to the development of English writing teaching, application of blog in English writing theory, which renders college English writing teaching well extended and complemented we should exert its advantages in order to realize students' active and cooperative learning. Teachers should accept and master such a new, free, equal and relaxing platform to improve the quality of teaching ultimately. However, there is a hard and long way to go to make full use of the superiority of the blog-based writing teaching, and improve the effect of blog-based writing teaching. It requires English teachers to make an exact orientation and strengthen their own quality and ability, to tighten the learning of the multimedia technology, and to make themselves skilled in mastering the multimedia technology, and actively take part in the research and study of the multimedia techniques, and improve and perfect the multimedia technologic teaching means and methods, finally get the new educational development in the new age.

At last, owing to my limited competence, the limitation exists in the thesis. Due to the limited access to the first hand materials, the collection of publicity materials is not enough, further researches in this area is needed. I hope college English writing teaching based on blog could achieve a new broke in the future and that my writing can offer some helpfulness to the latter resources.

\section{Bibliography}

[1] Huffaker,D. The Educated Blogger: Using Weblogs to Promote Literacy in the Classroom [J]. AACE journal, 2005, 13.

[2] Zhengjing Yu, Linsen Li; Jiwu Zhao. Practice and Reflection on College English Teaching[J]. Journal of Chengdu University of Information Technology, 2006, 5.

[3] Yibing YU. Integration of Blog in EFL Writing Classes[J]. Shanghai East China Normal University Publisher, 2007, 4.

[4] Xuefeng Zhang. The Application of Education Blog in Education and Teaching of Universities[J]. Journal of Changchun Normal University(Natural Science Edition), 2007, 4.

[5] Fukun Xing. Blog and Modern Foreign Language Teaching[J]. Modern Education Technology, 2007, 6.

[6] He Ying. The Application of College English Writing Teaching Based on Blog[J]. Scientific \& Technical Information of Gansu, 2008, 1.

[7] Xiaoying Guo. Teaching of College English Writing Based on Blog[J]. Journal of Zhongsan University, 2008, 6.

[8] Xiaoying Guo. Constructing College English Writing Mode Based on Blog[J]. Shandong Foreign Language Teaching Journal, 2009, 3.

[9] Xiaoying Guo. Design and Practice of College English Writing Mode Based on Blog [J]. Modern Foreign Languages, 2009, 3.

[10] Zou Su. Teaching Model of English Writing for English Majors Based on Blog[J]. Journal of Jilin Teachers Institute of Engineering and Technology, 2011, 1.

[11] Juanping Shao, Xiangyong Jiang. University English Writing Teaching Based on Blog ---Peer Feedback Mode to Discuss [J]. Journal of Zunyi Normal University, 2011, 1.

[12] Haiyan Zhang. An Empirical Study of University English Writing Teaching Based on Blog [J]. Journal of Changchun University of Science and Technology, 2011, 5.

[13] Tom Hutchinson, Alan Waters. English for Specific Purpose[M]. Shanghai: Shanghai Foreign Language Education Press, 2002, 10.

[14] Jo McDonough, Christopher Shaw. Materials and Methods in ELT: A Teacher's Guide [M]. Beijing: Peking University Press, 2004 (2): 27-28. 